Mathematic Education And Aplication Journal

Volume 1, No.1, Juli 2019, pp. 1-7

\title{
ETHNOMATHEMATICS: OPERASI BILANGAN BULAT PADA ATURAN “PETEMUAN” MASYARAKAT BALI
}

\author{
Jero Budi Darmayasa ${ }^{1}$, Wahyudin ${ }^{2}$, Tatang Mulyana ${ }^{3}$ \\ ${ }^{1}$ Jurusan Pendidikan Matematika, Universitas Borneo Tarakan \\ ${ }^{2}$ Jurusan Pendidikan Matematika, Universitas Pendidikan Indonesia \\ ${ }^{3}$ Jurusan Pendidikan Matematika, Universitas Siliwangi \\ ${ }^{1}$ jeromat@borneo.ac.id
}

\begin{abstract}
This qualitative research with case study model aims to explore ethnomathematics contained in the pre-marital culture of Balinese, especially the Bali Mula people. Based on the results of interviews, Focus Group Discussion (FGD), participant observation, and documentation analysis, it was found that there were several basic calculations in determining the merits of a mate in the Petemuan. After being examined and analyzed, the Ethnomathematics of the Petemuan was matched with the Number Operations in Junior High School Mathematics subjects.
\end{abstract}

Keywords: Ethnomathematics, Bali Mula, Number Operations.

\begin{abstract}
Abstrak
Penelitian kualitatif dengan model studi kasus ini bertujuan untuk mengeksplorsi ethnomathematics yang termuat dalam budaya pra-perkawinan masyarakat Bali, khususnya masyarakat Bali Mula. Berdasarkan hasil wawancara, Fokus Group Discussion (FGD), pengamatan berperanserta, dan analisis dokumentasi diperoleh bahwa terdapat beberapa perhitungan dasar dalam penentuan baik-buruknya jodoh dalam Petemuan. Setelah dicermasi dan dilakukan analisis, Ethnomathematics Petemuan tersebut berpadanan dengan materi Operasi Bilangan Bulat pada mata pelajaran Matematika jenjang Sekolah Menengah Pertama.
\end{abstract}

Kata kunci: Ethnomathematics, Bali Mula, Operasi Bilangan.

Meninjau landasan filosofi pengembangan ilmu pengetahuan, diketahui bahwa ada cabang ilmu pengetahuan baru yang berkembang dari ilmu pengetahuan yang lainnya. Proses tersebut diawali dengan adanya antitesis, sistesis, dan kemudian menghasilkan tesis yang baru. Hal itu berlangsung terus menerus bagaikan sebuah siklus, sehingga muncul berbagai ilmu pengetahuan baru seiring perkembangan jaman. Munculnya ilmu baru melalui tahapan-tahapan ilmiah termasuk didalamnya penelitian untuk menemukan teori dasar (grounded theory). Akhirnya antara teori yang satu dengan teori yang lainnya bisa saja memiliki irisan. Atau lebih luas lagi adanya irisan antara cabang ilmu yang satu dengan cabang ilmu yang lainnya.

Salah satu contoh nyata dari irisan beberapa cabang ilmu adalah Ethnomathematics (etnomatematika). Bahkan, ethnomathematics sebagai bidang kajian yang cukup baru didefinisikan dengan sangat variatif oleh para peminatnya. Namun yang paling dominan diatara definisi-definisi tersebut selalu mengaitkan ethnomathmetics dengan matematika dan budaya. Ada ahli yang menyatakan bahwa ethnomathematics sebagai antropologi budaya dari matematika dan pendidikan matematika, salah satunya untuk mengungkap titik temu antara matematika dan antropologi budaya (Gerdes, 1996). Ahli lain menyatakan bahwa ethnomathematics menggabungkan matematika yang dipraktikan, digunakan atau digabungkan secara sederhana dalam praktik budaya atau aktivitas oleh 
berbagai kelompok di masyarakat (Mosimege, 2004). Kedua definisi di atas memiliki kesamaan yang intinya menyebutkan bahwa ethnomathematics sebagai irisan matematika dan antropologi budaya.

Hal menarik yang perlu digarisbawahi berkaitan dengan hadirnya kajian ethnomathematics adalah perannya dimasa kini. Masa kini yang dimaksud adalah era revolusi industri 4.0 yang mana ciri khasnya digitalisasi. Bisa saja akan muncul anggapan bahwa tidak penting lagi untuk mengkai budaya leluhur di era sekarang. Jika hal tersebut terjadi maka pendidik akan berjuang lebih keras dalam membelajarkan matematika, karena pada dasarnya matematika seseorang dipengaruhi oleh latar budayanya, karena yang mereka lakukan berdasarkan apa yang mereka lihat dan rasakan atau alami (Zusmelia, 2016). Artinya kehadiran ethnomathematics sebagai bidang kajian yang baru seyogyanya menjadi jembatan penghubung atara kemajuan teknologi informasi dan komunikasi dengan budaya adi luhung yang mengalir dari generasi ke generasi masyarakat Indonesia.

Pemikiran memanfaatkan ethnomathematics sebagai jembatan penghubung antara arus globalisasi dan pelestarian budaya di Indonesia sejalan dengan kurikulum. Jika diperhatikan dengan seksama, landasan filosofi pengembangan kurikulum 2013 menjadikan budaya bangsa sebagai pijakan dalam mendidik generasi penerus. Artinya pemangku kebijakan dalam bidang pendidikan menyadari betul kekayaan budaya yang ada di Indonesia.

Melihat peluang tersebut, maka matematika sebagai salah satu mata pelajaran wajib hampir pada semua jenjang pendidikan memiliki peluang untuk mengambil peran strategis. Integrasi budaya dalam pembelajaran matematika sangat memungkinkan dengan adanya ethnomathematics. Pemikiran itu sejalan dengan pernyataan bahwa Etnomatematika hanyalah relevan untuk pembelajaran matematika dengan ranah Matematika Sekolah (Marsigit, 2016). Matematika sekolah yang dimaksudkan mengacu pada pemilahan oleh Ebbut dan Straker yang mendefiniskan Matematika Sekolah sebagai suatu kegiatan: Penelusuran pola dan hubungan, Intuisi dan investigasi, Komunikasi, dan Pemecahan masalah (Marsigit, 2016).

Untuk mewujudkan gagasan integrasi budaya dalam pembelajaran matematika di sekolah, maka langkah pertama yang harus dilakukan adalah eksplorasi ethnomathematics. Salah satunya adalah eksplorasi ethnomathematics pada masyarakat Bali. Budaya masyarakat Bali menjadi pilihan dalam kajian ini memperhatikan masyarakat Bali merupakan komunitas yang cukup kaya dengan budaya warisan leluhur. Disisi lain, posisinya sebagai daerah tujuan wisata menyebabkan arus globalisasi sangat deras di wilayah tersebut. Oleh karena itu, sebisa mungkin nilai-nilai luhur budaya di daerah tersebut perlu dikaji dan diintegrasikan dalam pembelajaran matematika. Tentu saja tidak terbatas pada pembelajaran matematika siswa di bali.

Sebagai suatu wilayah yang sudah dikenal masyarakat internasional tentang kekayaan budayanya, tentu banyak aspek yang bisa dieksplorasi pada budaya masyarakat Bali. Oleh karena itu, mengacu pada pemahaman awal tentang aturan "petemuan" atau baik-buruknya jodoh antara sepasang calon suami istri masyarakat Bali, muncul pertanyaan mendasar. Pertanyaan pertama yaitu apa saja aturan yang dipakai oleh masyarakat Bali untuk mengetahui baik-buruknya Petemuan?, kedua konsep 
matematika apa yang termuat dalam konsep Petemuan?, dan ketiga bagaimana pemetaannya dengan konsep matematika sekolah?.

\section{METODE}

Memperhatikan satuan kajian (unit analysis) dan fokus penelitian ini hanya pada ethnomathematics yang termuat dalam "petemuan" sebagai suatu tradisi berkaitan dengan perkawinan masyarakat Bali maka penelitian ini merupakan penelitian kualitaitif dengan model studi kasus. Beberapa teknik pengumpulan data dipilih dalam penelitian ini diantaranya wawancara, observasi, FGD, dan analisis dokumentasi. Wawancara dilakukan karena sebagian informasi yang diharapkan tidak memungkinkan dilakukan melalui metode tes ataupun angket (Ruseffendi, 2005). Informan yang diwawancarai diantaranya beberapa pasangan suami istri masyarakat Bali Mula di kawasan Kaldera Batur dan juga tokoh masyarakat. Sementara itu, analisis dokumentasi dilakukan dengan mencermati naskah atau buku-buku yang kuno yang memuat aturan tentang petemuan.

Selama hampir 10 bulan berinteraksi dengan masyarakat Bali Mula di kawasan Kintamani, peneliti berkesempatan menghadiri upacara perkawinan dan diskusi dengan mereka. Informan dalam penelitian ini diantaranya Jero Karba sebagai wali dari pasangan pengantin Nova dan Luh; I Nengah Artawan, M.Ag sebagai pemerhati agama dan budaya dari Banjar Kayuselem, Songan B Kintamani; Mangku Diun sebagai tokoh masyarkat Banjar Kendal, Desa Songan yang mendalami Pedewasaan; I Lusin warga banjar Kayuselem yang mengerti tentang Pedewasaan, Jero Penyarikan Apun sebagai Tokoh Masyarakat dan Mantan Sekretaris (Penyarikan) Desa Adat Songan, I Wayan Satu Arta dan Ni Suindi sebagai sepasang suami istri; Jero Muada, dan Mangku Ragia. Data hasil penelitian juga banyak diperoleh dari hasil diskusi dengan masyarakat Desa Songan, masyarakat Desa Belandingan, serta Masyarakat Desa Terunyan.

Masyarakat pada ketiga desa tersebut sebagian besar merupakan keturunan warga Bali Mula. Masyarakat bali mula yang dimaksud baik sebagai warga pasek Kayuselem, Celagi, Terunyan, ataupun Kayuan (Riana, 2011). Hasil wawancara, observasi, dan FGD kemudia dipadukan dengan hasil analisis dokumentasi sebagai bentuk uji keabsahan data. Pengamatan berulang, penelitian partisipatori, dan pengecekan bias peneliti juga dilakukan untuk memastikan validitas data hasil penelitian (Creswell, 2014). Data yang valid kemudian disajikan dan dipetakan dengan konsep matematika sekolah.

\section{HASIL DAN PEMBAHASAN}

Setiap daerah di Indonesia memiliki tradisi yang unik berkaitan dengan aktivitas penting di keluarganya. Kelahiran, pernikahan, kesembuhan, kesuksesan, ataupun kematian pada umunya diperingati dalam bentuk syukuran. Seiring perkembangan jaman, ada daerah yang masih menjaga dengan sangat ketat budayanya. Namun aada juga daerah yang sangat terbuka terhadap arus globalisasi, sehingga sangat sulit mengenali budaya asli di daerahnya. Suku Badui Dalam misalnya sebagai masyarakat yang sangat ketat dalam menjaga budaya warisan para leluhurnya. 
Mirip dengan suku Badui, masyarakat Bali juga cukup ketat dalam menjada budaya warisan para leluhur. Sebagai contoh tradisi menghitung baik-buruknya jodoh yang dikenall dengan istilah Petemuan. Masyarakan Bali pada umumnya, termasuk juga masyarakat Bali Mula masih terus berusaha melestarikan budaya petemuan. Sebagian besar dari mereka meyakini petemuan memberikan pengaruh yang besar tehadap kehidupan sosial ekonomi pasangan yang menjalaninya.

Sebelum melihat aturan-aturan yang ada, terlebih dahulu perlu dipahami tentang jenis-jenis "Minggu" yang digunakan oleh masyarakat Bali. Terdapat 10 jenis "Minggu" yang masih kental digunakan di Bali dan dikenal dengan istilah Wewaran. Kesepuluh minggu tersebut diantaranya Eka Wara (minggu yang hanya terdiri dari 1 hari), Dwi Wara (Minggu yang hanya terdiri dari dua hari), sampai dengan Dasa Wara (minggu yang terdiri dari 10 hari). Setiap hari pada "Minggu" memiliki urip/neptu berupa angka (Tabel 1). Urip itulah yang dijadikan sebagai salah satu acuan dalam menghitung baik buruknya petemuan sepasang kekasih.

Tabel 1. Urip masing-masing hari dalam Wewaran

\begin{tabular}{|c|c|c|c|c|c|}
\hline Wewaran & Nama Hari & Wewaran & Nama Hari & Wewaran & Nama Hari \\
\hline Ekawara & Luang (9) & \multirow[t]{3}{*}{ Sadwara } & Paniron (8) & \multirow{9}{*}{ Sangawara } & Dangu (5) \\
\hline \multirow{2}{*}{ Dwiwara } & Menga (5) & & Was (9) & & Jangur (8) \\
\hline & Pepet (4) & & Maulu (3) & & Gigis (9) \\
\hline \multirow{3}{*}{ Triwara } & Pasah (4) & \multirow[t]{8}{*}{ Saptawara } & Redite/Minggu (5) & & Nohan (3) \\
\hline & Beteng (4) & & Soma/Senin (4) & & Ogan (7) \\
\hline & Kajeng (7) & & Anggara/Selasa (3) & & Erangan (1) \\
\hline \multirow{4}{*}{ Caturwara } & Sri (6) & & Buda/Rabu (7) & & Urungan (4) \\
\hline & Laba (5) & & Warespati/Kamis(8) & & Tulus (6) \\
\hline & Jaya (1) & & Sukra/Jumat(6) & & Dadi (8) \\
\hline & Menala (8) & & Saniscara/Sabtu (9) & \multirow{10}{*}{ Dasawara } & Pandita (5) \\
\hline \multirow{5}{*}{ Pancawara } & Umanis (5) & & & & Pati (7) \\
\hline & Paing (9) & Astawara & Sri (6) & & Suka (10) \\
\hline & Pon (7) & & Indra (5) & & Duka (4) \\
\hline & Wage (4) & & Guru (8) & & Sri (1) \\
\hline & Kliwon (8) & & Yama (9) & & Manuh (2) \\
\hline \multirow{4}{*}{ Sadwara } & Tungleh (7) & & Ludra (3) & & Manusa (3) \\
\hline & Aryang (6) & & Brahma (7) & & Raja (8) \\
\hline & Urukung (5) & & Kala (1) & & Dewa (9) \\
\hline & & & Uma (4) & & Raksasa (1) \\
\hline
\end{tabular}

Setelah memahami urip masing-masing hari, maka aturan-aturan akan lebih mudah diterapkan. Adapun beberapa acuan/aturan yang biasa digunakan untuk mengetahui baik buruknya petemuan suami istri yang diringkas dari beberapa buku sebagai hasil kajian literatur:

\section{1) Acuan 1: (Urip Sapta-wara + Urip Panca-Wara + Urip Sad-Wara Lanang (Laki-laki)-Istri (Perempuan))/16 (Guweng, -)}

Berikut ini petemuan yang baik dilihat dari sisa hasil pembagian.

a) Jika bersisa 5 maka "Melah lunas-lanus", meningkat terus

b) Jika bersisa 7 maka "Suka-duka", meningkat tetapi sangat lambat 
c) Jika bersisa 10 maka "Melah bikas ratu pinanggih", berwibawa

d) Jika bersisa 11 maka "Sebita", selalu dalam keadaan puas

e) Jika bersisa 12 maka "Sedana lulus", murah rejeki

f) Jika bersisa 13 maka "Ageng lama, panjang yusa", kekal dan panjang umur

g) Jika bersisa 14 maka "Dahating bagia", berbahagia

h) Jika habis dibagi maka "Temonin", selalu rukun

2) Acuan 2: Dengan menjumlahkan Neptu Saptawara dan Pancawara hari lahir suami (lakilaki) dan menjumlahkan Neptu Saptawara dan Pancawara hari lahir Istri (perempuan) kemudian masing-masing dibagi 9. Perhatikan yang laki-laki bersisa berapa dan yang perempuan bersisa berapa (Simpen, 1987)

Baik buruknya dilihat dari hubungan kedua sisanya. Berikut ini adalah petemuan yang baik, daintaranya:

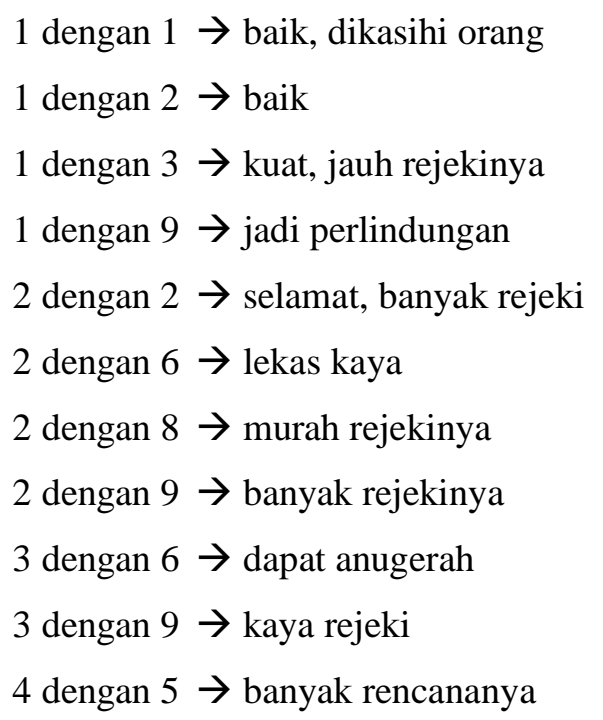

4 dengan $6 \rightarrow$ kaya rejeki

4 dengan $8 \rightarrow$ banyak pangkalnya

5 dengan $5 \rightarrow$ terus kebaikannya

5 dengan $6 \rightarrow$ rejekinya banyak

5 dengan $7 \rightarrow$ jadilah sandang pangannya

5 dengan $8 \rightarrow$ banyak cita-citanya

5 dengan $9 \rightarrow$ murah sandang pangannya

6 dengan $7 \rightarrow$ rukun dan damai

7 dengan $8 \rightarrow$ dikasihi oleh orang

7 dengan $9 \rightarrow$ terus pala karmanya

8 dengan $8 \rightarrow$ dikasihi oleh orang

3) Acuan 3: Menggunakan Nama Sebenarnya (Simpen, 1987)

Acuan ini menggunakan nama asli (yang diberikan orang tua) laki-laki dan nama asli perempuan yang menjadi pasangannya. Yang diambil hanya huruf (suku) di depan dan huruf (suku) di belakang. Neptu huruf yang telah diambil kemudian dijumlahkan lalu dibagi sembilan. Begitu juga untuk nama perempuan (pasangannya). Masing-masing sisa pembagian dengan sembilan kemudian dipasang-pasangkan. Petemuan baik jika hubungan kedua sisanya, sebagai berikut:

\begin{tabular}{|c|c|c|c|c|c|}
\hline 1 dengan 1 & $\rightarrow$ baik & 2 dengan 8 & $\rightarrow$ kuat & 6 dengan 7 & $\rightarrow$ baik \\
\hline 1 dengan 2 & $\rightarrow$ baik & 2 dengan 9 & $\rightarrow$ baik & 6 dengan 8 & $\rightarrow$ baik \\
\hline 1 dengan 9 & $\rightarrow$ jadi pemimpin & 3 dengan 6 & $\rightarrow$ baik & 7 dengan 7 & $\rightarrow$ baik \\
\hline 2 dengan 2 & $\rightarrow$ baik & 3 dengan 9 & $\rightarrow$ baik & 7 dengan 8 & $\rightarrow$ baik \\
\hline 2 dengan 4 & $\rightarrow$ baik & 5 dengan 9 & $\rightarrow$ baik & 8 dengan 8 & $\rightarrow$ baik \\
\hline
\end{tabular}

Neptu huruf:

$\mathrm{H}(\mathrm{a}, \mathrm{i}, \mathrm{u}, \mathrm{e}, \mathrm{o})=1 \quad \mathrm{~T}=7 \quad \mathrm{~S}=9 \quad \mathrm{~W}=1 \quad \mathrm{~L}=1$ 


$\begin{array}{lllll}\mathrm{P}=7 & \mathrm{Dh}=3 & \mathrm{~J}=6 & \mathrm{Y}=5 & \mathrm{Ny}=10 \\ \mathrm{M}=4 & \mathrm{G}=2 & \mathrm{~B}=4 & \mathrm{Th}=9 & \mathrm{Ng}=10 \\ \mathrm{~N}=3 & \mathrm{C}=5 & \mathrm{R}=7 & \mathrm{~K}=2 & \mathrm{D}=4\end{array}$

4) Acuan 5: Menggunakan Neptu hari Lahir Pasangan (Simpen, 1987)

Jumlah urip satpawara dan pancawara hari lahir laki dan perempuan dijumlahkan lalu dibagi sepuluh atau tujuh. Jika setelah dibagi dengan sepuluh menghasilkan sisa lebih dari tujuh maka bagi lagi dengan tujuh. Petemuan baik jika sisanya berikut ini:

a) Jika sisa 1 disebut Wisesa Segara: Luas budinya, kaya, sabar, besar prabawanya

b) Jika sisa 2 disebut Tunggak Semi: sedikit rejekinya

c) Jika sisa 3 disebut Satria Wibawa: dapat kemuliaan dan keluhuran

d) Jika sisa 6 disebut Bumi Kapetak: gelap budinya, tetapi rajin bekerja, kuat menderita sakit dan lapar, suka kebersihan.

\section{5) Acuan 6: Berdasarkan Neptu Pancawara dan Saptawara (Upada Sastra, 1992)}

Jumlahkan neptu Pancawara dan Saptawara laki-laki dan pasangannya kemudian dibagi 4 atau dibagi 5. Petemuan baik jika dengan ketentuan:

a. Jika dibagi 4.

Sisa $2=$ Gembali berarti banyak anak

Sisa 3 = Sugih berarti banyak rejeki b. Jika dibagi 5 .

Sisa 1, Sri (banyak rejeki)

Sisa 2, Dana (keadaan keuangannya baik)

Habis, Lungguh (mendapatkan kedudukan)

Aturan-aturan di atas diperoleh dari hasil analisis dokumentasi berupa buku-buku Wariga Dewasa. Untuk menguji keabsahannya, dilakukan wawancara, FGD, dan pengamatan berperanserta. Pengamatan berperanserta dilakukan dengan menghadiri prosesi perkawinan beberapa pasangan masyarakat desa Songan. Pada umumnya, mereka meyakini bahwa banyak sedikitnya anak dalam sebuah keluarga, gagal atau suksesnya dalam bidang ekonomi, baik buruknya kesehatan dipengaruhi juga oleh petemuan pasangan bersangkutan. Memang untuk saat ini tradisi tersebut untuk masyarakat desa Songan mulai berkurang pengaruhnya jika dibandingkan 15-20 tahun yang lalu.

Informasi tersebut diperoleh dari hasil FGD non-formal yang memberikan informasi bahwa tidak sedikit sepasang kekasih atau seorang pemuda/pemudi beberapa tahun yang lalu yang mengurungkan niatnya menuju hubungan yang lebih serius ketika mendapatkan saran dari orang tua atau orang terdekatnya berkaitan dengan Petemuan mereka. Salah satu informan yang dengan tegas mencertiakan pengalamannya yaitu Jero Muada. "Gus to bli maan demen ajak cewek, kola Hyang-e Wa Guru Siyem nampat, jelek ranga petemuane, buung sanga" Kata beliau. Pernyataan di atas dapat diartikan "Waktu itu Bli (Kakak) pernah jatuh hati sama seorang gadis, namun Dewa Hyang (Almarhum, telah diaben) Paman Guru Siyem menasehati, katanya "petemuannya" tidak baik, makanya batal". Pengalaman seperti yang disampaikan Jero Muada dibenarkan oleh adiknya Mangku Ragia. Beliau menceritakan pengalamannya pada masa muda terkait dengan Petemuan. 
Lalu bagaimana jika sepasang suami istri sudah terlanjur menikah dan baru menyadari bahwa petemuan mereka kurang bagus?. Hal itu juga tertuang pada salah satu buku wariga dewasa yang memuat aturan baik-buruknya petemuan berdasarkan nama pasangan laki-laki dan pasangan perempuan. Oleh karena itu, ada juga pasangan suami-istri yang melaksanakan Upacara Perubahan Nama untuk memperbaiki petemuan-nya. Meskipun ada penurunan kesadaran masyarakat dalam mengimplementasikan aturan tersebut saat ini, hal baiknya adalah panduan untuk menghitungnya saat ini mudah ditemukan pada buku-buku ataupun warisan tak-benda berupa pengetahuan masyarakat. Sehingga integrasi pada pembelajran matematika melalui ethnomathematics diharapkan dapat menjaganya dari kepunahan.

\section{KESIMPULAN}

Dari temuan di atas dapat disimpulkan bahwa operasi bilangan bulat berupa penjumlahan, pembagian, dan juga sisa hasil pembagian diterapkan dalam menghitung baik-buruknya petemuan. Lebih dari itu, penguasaan konsep relasi antara dua himpuan juga penting dikuasai oleh masyarakat Bali Mula (khususnya pemerhati Wariga Dewasa) dalam menentukan baik-buruknya petemuan.

\section{UCAPAN TERIMA KASIH}

Terima kasih kepada Direktorat Riset dan Pengabdian Masyarakat, Direktorat Jenderal Penguatan Riset dan Pengembangan, Kementerian Riset Teknologi dan Pendidikan Tinggi atas dana hibah penelitian disertasi doktor tahun 2018.

\section{DAFTAR PUSTAKA}

Creswell, J. W. (2014). Research Design: Qualitative, Quantitative, and Mixed Methods Approaches. Los Angeles: SAGE.

Gerdes, P. (1996). Ethnomathematics and Mathematics Education. In K. C. Alan J Bishop, International Handbook of Mathematics Education (Part Two) (pp. 909-943). Netherlands: Kluwer Academic Publishers.

Guweng, I. K. (1991). Sarining Wariga. Denpasar: C2.

Marsigit. (2016). Pengembangan Pembelajaran Matematika Berbasis Etnomatematika. Seminar Nasional Matematika dan Pendidikan Matematika (pp. 1-32). Padang: STKIP PGRI Sumatera Barat.

Mosimege, M. (2004). Ethnomathematical Studies on Indegenous Games: Examples from Southern Africa. Ethnomathematics and Mathematics Education (pp. 119-137). Pisa: Tipografia Editrice Pisana.

Riana, I. K. (2011). lalintih Sang Catur Sanak Bali: kayuselem, Celagi, Tarunyan, Kaywan, Lan Warga Bali Aga. Denpasar: Yayasan Tan Mukti Palapa.

Ruseffendi, E. (2005). Dasar-dasar Penelitian Pendidikan \& Bidang Non-Eksata Lainnya. Bandung: Tarsito.

Zusmelia. (2016). Matematika dalam Perspektif Indegenous People dan Indegeneous Knowledge (Kasus pada Masyarakat Matrilineal Minangkabau Sebuah Tinjauan Sosiologis). Seminar Nasional Matematika dan Pendidikan Matematika (pp. 1-12). Padang: STKIP PGRI Sumatera Barat. 